\title{
Ocean acidification from 1997 to 2011 in the subarctic western North Pacific Ocean
}

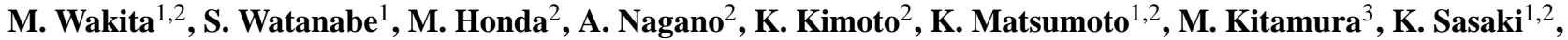 \\ H. Kawakami ${ }^{1,2}$, T. Fujiki ${ }^{2}$, K. Sasaoka ${ }^{2}$, Y. Nakano ${ }^{4}$, and A. Murata ${ }^{2}$ \\ ${ }^{1}$ Mutsu Institute for Oceanography, Japan Agency for Marine-Earth Science and Technology, Mutsu, Japan \\ ${ }^{2}$ Research Institute for Global Change, Japan Agency for Marine-Earth Science and Technology, Yokosuka, Japan \\ ${ }^{3}$ Institute of Biogeosciences, Japan Agency for Marine-Earth Science and Technology, Yokosuka, Japan \\ ${ }^{4}$ Marine Technology and Engineering Center, Japan Agency for Marine-Earth Science and Technology, Yokosuka, Japan
}

Correspondence to: M. Wakita (mwakita@jamstec.go.jp)

Received: 28 March 2013 - Published in Biogeosciences Discuss.: 16 May 2013

Revised: 25 September 2013 - Accepted: 24 October 2013 - Published: 2 December 2013

\begin{abstract}
Rising atmospheric $\mathrm{CO}_{2}$ contents have led to greater $\mathrm{CO}_{2}$ uptake by the oceans, lowering both $\mathrm{pH}$ due to increasing hydrogen ions and $\mathrm{CaCO}_{3}$ saturation states due to declining carbonate ion $\left(\mathrm{CO}_{3}^{2-}\right)$. Here we used previously compiled data sets and new data collected in 2010 and 2011 to investigate ocean acidification of the North Pacific western subarctic gyre. In winter, the western subarctic gyre is a source of $\mathrm{CO}_{2}$ to the atmosphere because of convective mixing of deep waters rich in dissolved inorganic carbon (DIC). We calculated $\mathrm{pH}$ in winter mixed layer from DIC and total alkalinity (TA), and found that it decreased at the rate of $-0.0011 \pm 0.0004 \mathrm{yr}^{-1}$ from 1997 to 2011. This decrease rate is slower than that expected under the condition of seawater/atmosphere equilibration, and it is also slower than the rate in the subtropical regions $\left(-0.002 \mathrm{yr}^{-1}\right)$. The slow rate is caused by a reduction of $\mathrm{CO}_{2}$ emission in winter due to an increase in TA. Below the mixed layer, the calcite saturation horizon ( $\sim 185 \mathrm{~m}$ depth) shoaled at the rate of $2.9 \pm 0.9 \mathrm{~m} \mathrm{yr}^{-1}$ as the result of the declining $\mathrm{CO}_{3}^{2-}$ concentration $\left(-0.03 \pm 0.01 \mu \mathrm{mol} \mathrm{kg}^{-1} \mathrm{yr}^{-1}\right)$. Between $200 \mathrm{~m}$ and $300 \mathrm{~m}$ depth, $\mathrm{pH}$ decline during the study period $\left(-0.0051 \pm 0.0010 \mathrm{yr}^{-1}\right)$ was larger than ever reported in the open North Pacific. This enhanced acidification rate below the calcite saturation horizon reflected not only the uptake of anthropogenic $\mathrm{CO}_{2}$ but also the increase in the decomposition of organic matter evaluated from the increase in AOU, which suggests that the dissolution of $\mathrm{CaCO}_{3}$ particles increased.
\end{abstract}

\section{Introduction}

Globally, anthropogenic $\mathrm{CO}_{2}$ was taken up by the oceans at a rate of $2.2 \pm 0.4 \mathrm{Pg} \mathrm{Cyr}^{-1}$ during the $1990 \mathrm{~s}$ (Bindoff et al., 2007). This $\mathrm{CO}_{2}$ uptake by the oceans has increased the hydrogen ion $\left(\mathrm{H}^{+}\right)$concentration (i.e., lowered the $\mathrm{pH}$ ) and lowered the $\mathrm{CaCO}_{3}$ saturation state $(\Omega)$, by decreasing the carbonate ion $\left(\mathrm{CO}_{3}^{2-}\right)$ concentration, thereby leading to bicarbonate ion $\left(\mathrm{HCO}_{3}^{-}\right)$formation. These changes in the carbonate system affect marine organisms and ecosystems throughout the world's oceans (Doney et al., 2009).

Ocean acidification of surface and subsurface waters of the North Pacific Ocean has been clearly documented in time series and repeat hydrography data (direct basin-wide observations) over the past two decades (e.g., Dore et al., 2009; Byrne et al., 2010; Midorikawa et al., 2010, Ishii et al., 2011; Feely et al., 2004; Feely et al., 2012; Murata and Saito, 2012). The observed $\mathrm{pH}$ changes in the surface ocean are consistent with those predicted based on equilibration of atmospheric $\mathrm{CO}_{2}$ with the seawater (about $-0.002 \mathrm{yr}^{-1}$ ) (Dore et al., 2009; Byrne et al., 2010; Midorikawa et al., 2010; Ishii et al., 2011). In subsurface water, $\mathrm{pH}$ decreases $\left(-0.003 \mathrm{yr}^{-1}\right.$ at Station ALOHA $\left(22.75^{\circ} \mathrm{N} ; 158^{\circ} \mathrm{W}\right.$; Dore et al. (2009) and $0.004 \mathrm{yr}^{-1}$ in North Pacific Intermediate Water; Byrne et al. (2010)) have been enhanced by the accumulation of anthropogenic $\mathrm{CO}_{2}$ and by natural variability related to temporal changes in physical and biogeochemical processes such as ocean ventilation, and remineralization of organic matter related to apparent oxygen utilization (AOU). The downward 


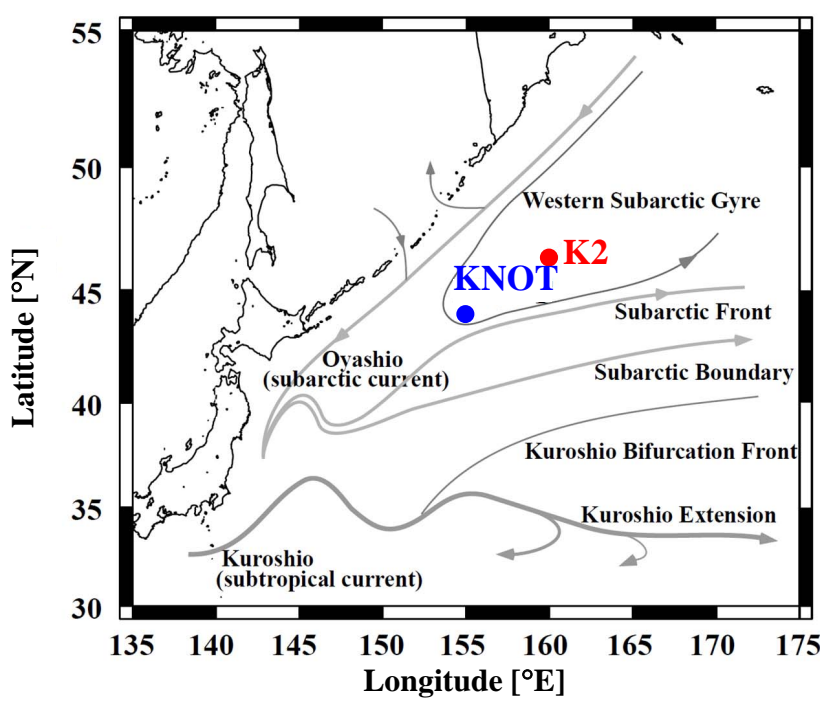

Fig. 1. Time-series stations and the main ocean currents in the western North Pacific.

transport of anthropogenic $\mathrm{CO}_{2}$ taken up by the oceans since the preindustrial era has caused shoaling of the $\mathrm{CaCO}_{3}$ saturation horizons of both aragonite and calcite in the North Pacific (Feely and Chen, 1982; Feely et al., 2004, 2012; Murata and Saito, 2012). These results are caused by an increase of $\mathrm{H}^{+}$(i.e., a decrease of $\mathrm{pH}$ ) and a concurrent decrease of $\mathrm{CO}_{3}^{2-}$ concentration, and will impact many marine calcifying species in surface and subsurface water of North Pacific (e.g., coccolithophores, foraminifera, and pteropods). Furthermore, the observed increase in total alkalinity (TA) at the depth of the aragonite saturation horizon between 1970 and 1990 is consistent with the calculated increase in $\mathrm{CaCO}_{3}$ dissolution caused by the shoaling of the horizon (Sarma et al., 2002), although the uncertainty is large (Bindoff et al., 2007).

Projections of the $\mathrm{CaCO}_{3}$ saturation horizon of aragonite based on the Intergovernmental Panel on Climate Change (IPCC) IS92a scenario (an atmospheric $\mathrm{CO}_{2}$ concentration of $788 \mathrm{ppmv}$ in 2100) for future emissions of anthropogenic $\mathrm{CO}_{2}$ indicate that the surface mixed layer $(0-100 \mathrm{~m})$ in the Southern Ocean, and the subarctic Pacific Ocean will become undersaturated with respect to aragonite around 2020-2040 (Orr et al., 2005; Guinotte et al., 2006). For this reason, seawater at the high latitudes has a high Revelle factor, which is a low $\mathrm{CO}_{2}$ buffering capacity in seawater, and is characterized by low concentrations of $\mathrm{CO}_{3}^{2-}$ and shallow of $\mathrm{CaCO}_{3}$ saturation horizon (Takahashi et al., 2006; Feely et al., 2004). Thus, even if a smaller change in $\Omega$ accompanies future increases in atmospheric $\mathrm{CO}_{2}$, the surface waters in these regions will be the first to switch from being supersaturated to being undersaturated with respect to $\mathrm{CaCO}_{3}$. In particular, models project that the first region to become undersaturated will be the western subarctic North Pacific (Fig. 1) during winter (Orr et al., 2005; Guinotte et al., 2006), because win- tertime surface waters in this region have lower $\Omega$ content and shallower $\mathrm{CaCO}_{3}$ saturation horizon (Fig. 2) than the open Pacific Ocean and Southern Ocean (Feely et al., 2004; Feely et al., 2012). The lower $\Omega$ in the winter is caused by the convective mixing of deep waters rich in dissolved inorganic carbon (DIC), accompanying with a strong $\mathrm{CO}_{2}$ source (e.g., Tsurushima et al., 2002; Wakita et al., 2010a) (Fig. 2). These results mean that in this region, ocean acidification in winter is affected not only by increases in atmospheric $\mathrm{CO}_{2}$ but also by decadal variations of $\mathrm{CO}_{2}$ emissions. Therefore, assessment of the present progression of acidification in winter in the western subarctic gyre of the North Pacific from field observations is an urgent task.

In this study, we are aimed at clarifying progression of ocean acidification in winter in the western subarctic gyre by examining the temporal changes of $\mathrm{pH}$ and $\mathrm{CaCO}_{3}$ saturation horizon, which are indicators of ocean acidification, and related chemical properties (dissolved inorganic carbon (DIC), TA, and oceanic $\mathrm{CO}_{2}$ ) below the winter mixed layer at two time-series stations (K2 and KNOT) during the period 1997-2011 (Fig. 1).

\section{Data and analyses}

From January 2010 to July 2011, we conducted hydrographic observations at stations K2 and KNOT during five cruises (MR10-01, January to February 2010; MR10-06, October 2010; MR11-02, February to March 2011; MR11-03, April 2011, and MR11-05, July 2011) of the R/V Mirai of the Japan Agency for Marine-Earth Science and Technology. These observations comprised 20 CTD casts at K2, and in four CTD casts at KNOT. DIC and TA were measured by using coulometric and potentiometrical techniques, respectively. Those values were calibrated against certified reference material provided by A. G. Dickson (Scripps Institution of Oceanography). The precision of both DIC and TA was $\pm 0.1 \%$. Dissolved oxygen (DO) and nutrients (silicate, phosphate, and nitrate) concentrations were measured with an automatic photometric titrator and a continuous flow analyzer, respectively. Data sets collected at K2 and KNOT from 2010 to 2011 will be opened to publish on the JAMSTEC data web site (http://ebcrpa.jamstec.go. $\mathrm{jp} / \mathrm{k} 2 \mathrm{~s} 1 / \mathrm{en} / \mathrm{index} . \mathrm{html}$ ) and the Carbon Dioxide Information and Analysis Center web site (http://cdiac.ornl.gov/oceans/ Moorings/K2.html). We also merged compiled data sets from KNOT and K2 for the period 1997-2008, in which the systematic errors were corrected (Wakita et al., 2010b, c). In addition, we used oceanic physical and chemical data collected at KNOT and K2 during WOCE-P1 (2007) (Fukasawa et al., 2008).

K2 and KNOT are both located in the western subarctic gyre (Fig. 1). We obtained a decadal time series by combining data from the two stations, because the duration of sampling at each individual station data was not sufficient. 

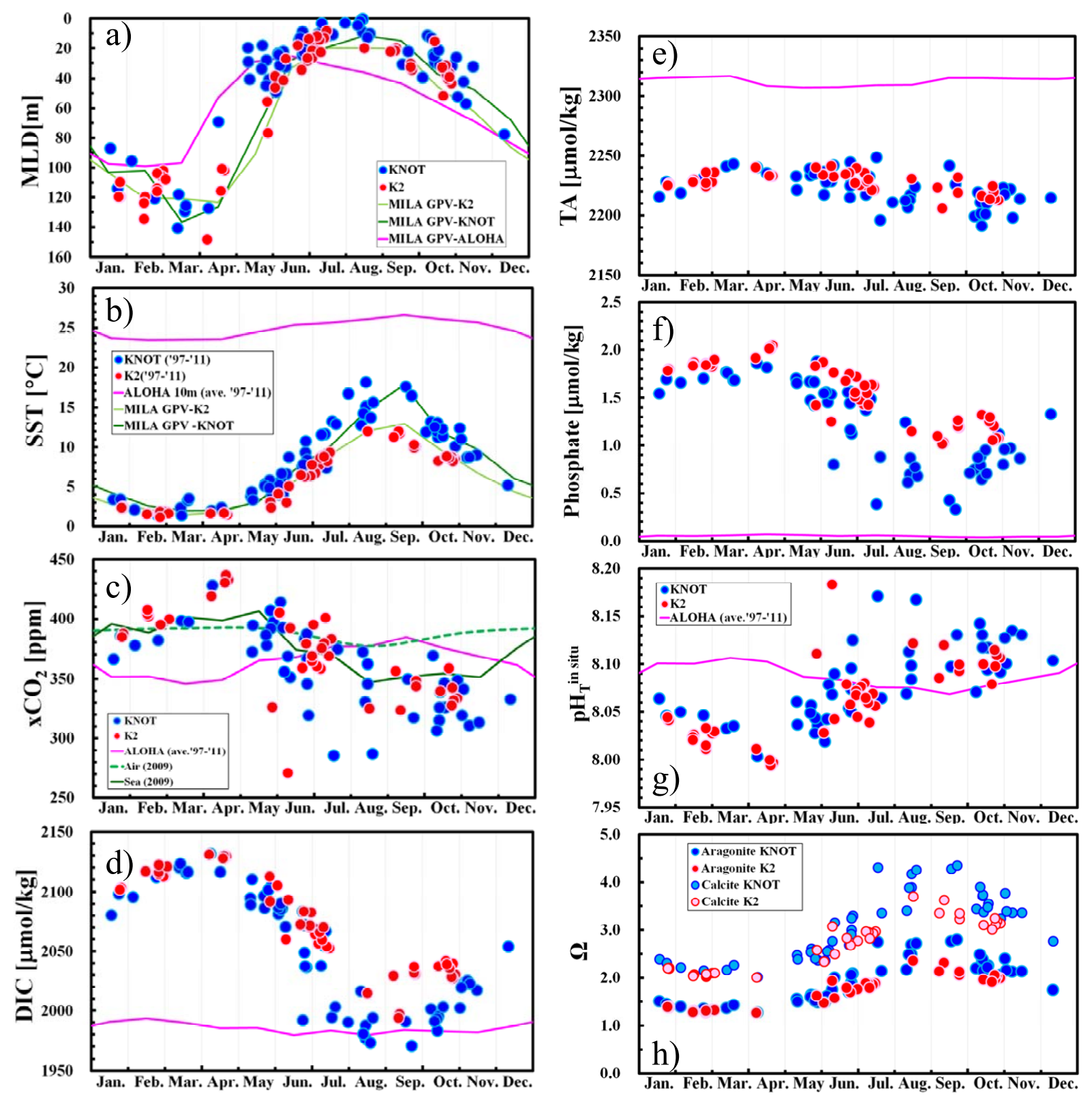

Fig. 2. Seasonal variations of (a) the maximum mixed-layer depth (MLD), (b) sea surface temperature (SST), (c) oceanic and atmospheric $x \mathrm{CO}_{2}$, (d) DIC, (e) TA, (f) phosphate, (g) $\mathrm{pH}$ (total scale) at the in situ temperature $\left(\mathrm{pH}_{T}^{\text {in situ }}\right.$ ), and $(\mathbf{h}) \mathrm{CaCO}_{3}$ saturation states $(\Omega)$ with respect to aragonite and calcite in the surface mixed layer at KNOT (blue circles) and K2 (red circles). These figures were plotted using all data from 1997 to 2011 in order to examine typical seasonal variations and for comparison with the climatological monthly means of MIxed Layer data set of Argo, Grid Point Value (MILA GPV) (Hosoda et al., 2010) (a, b), data from Station ALOHA (Dore et al., 2010) (b-g), and Takahashi et al. (2009) (c). Values of oceanic $x \mathrm{CO}_{2}(\mathbf{c}), \mathrm{pH}_{T}^{\text {in situ }}(\mathbf{g})$ and $\Omega(\mathbf{h})$ were calculated from TA and DIC. The density criterion in the surface mixed layer was smaller than $0.125 \mathrm{~kg} \mathrm{~m}^{-3}$ (de Boyer Montégut et al., 2004).

Typically, in this region the minimum temperature $\left(T_{\min }\right)$ in the water column is associated with the remnant of the mixed layer water in the preceding winter and occurs at about $26.5 \sigma_{\theta}(\sim 100 \mathrm{~m})$, and the maximum temperature occurs at about 27.1 $\sigma_{\theta}(\sim 370 \mathrm{~m})$ (e.g., Ueno and Yasuda, 2000; Osafune and Yasuda, 2006). Each year, the surface mixed layer reached its maximum depth from mid-March to early April (Fig. 2a) and the coldest mixed-layer temperatures were observed in early April (Fig. 2b). Because spring to fall surface mixed layer temperatures did not influence $T_{\min }$ (Wakita et al., 2010a), we identify the $T_{\min }$ layer as the remnant of the winter (early April) mixed-layer water. However, station 
KNOT is just north of the subarctic front (Fig. 1), so occasionally no $T_{\min }$ water is observed because of the northward migration of subtropical water (Tsurushima et al., 2002). Because this migrated subtropical water enters the south edge of western subarctic gyre and passes eastward (Ueno and Yasuda, 2000), we did not use observation data if no $T_{\min }$ layer could be identified. This indicates the combined $\mathrm{K} 2$ and KNOT data in this study does not include the subtropical water and is not obviously different in hydrography.

DIC, TA, phosphate, silicate and AOU in the winter mixed layer (i.e., $\mathrm{DIC}_{\text {win }}, \mathrm{TA}_{\text {win }}, \mathrm{PO}_{4}$ win $, \mathrm{Si}_{\text {win }}, \mathrm{AOU}_{\text {win }}$ ) are obtained from in the corresponding values in the $T_{\min }$ layer $\left(\mathrm{DIC}_{T \text { min }}, \mathrm{TA}_{T \text { min }}, \mathrm{PO}_{4} T_{\text {min }}, \mathrm{Si}_{T \text { min }}\right.$ and $\mathrm{AOU}_{T \text { min }}$ ) following Wakita et al. (2010a). $\mathrm{DIC}_{T \min }, \mathrm{AOU}_{T \min }, \mathrm{PO}_{4} T_{\text {min }}$, and $\mathrm{Si}_{T \text { min }}$ varied seasonally, reaching minima in winter, but $\mathrm{TA}_{T \text { min }}$ showed no distinct seasonal variation (Wakita et al., 2010a). In spring, observed values of $\mathrm{DIC}_{T \min }, \mathrm{AOU}_{T \min }$, $\mathrm{PO}_{4} T_{\text {min }}$, and $\mathrm{Si}_{T \text { min }}$ increased compared with those of the previous winter because of the decomposition of organic matter. We calculated AOU by subtracting the observed DO concentration from the saturated concentration calculated from temperature and salinity using the equation of Weiss (1970). We assumed that DO in the winter mixed layer was homogeneously saturated (i.e., $\mathrm{AOU}=0$ ) because of strong vertical mixing and air-sea exchange. We calculated $\mathrm{DIC}_{\text {win }}$, $\mathrm{PO}_{4}$ win , and $\mathrm{Si}_{\text {win }}$ from observed $\mathrm{DIC}_{T \text { min }}, \mathrm{PO}_{4} T_{\text {min }}$, and $\mathrm{Si}_{T \text { min }}$, and stoichiometric ratios of decomposition with the following equations:

$\mathrm{DIC}_{\mathrm{win}}=\mathrm{DIC}_{T \text { min }}-\left(\mathrm{C} /-\mathrm{O}_{2}\right) \times \mathrm{AOU}_{T \text { min }}$

$\mathrm{PO}_{4 \text { win }}=\mathrm{PO}_{4 T \text { min }}-\left(\mathrm{P} /-\mathrm{O}_{2}\right) \times \mathrm{AOU}_{T \text { min }}$

$\mathrm{Si}_{\text {win }}=\mathrm{Si}_{T \text { min }}-\left(\mathrm{Si} /-\mathrm{O}_{2}\right) \times \mathrm{AOU}_{T \text { min }}$,

where $\left(\mathrm{C} /-\mathrm{O}_{2}\right)(117 / 170)$ and $\left(\mathrm{P} /-\mathrm{O}_{2}\right)(1 / 170)$ are the stoichiometric ratios of carbon and phosphorus to oxygen during the decomposition of organic matter (Anderson and Sarmiento, 1994). We used $\left(\mathrm{Si} /-\mathrm{O}_{2}\right)$ of 0.18 because $\mathrm{Si}_{T \text { min }}$ was positively correlated with $\mathrm{AOU}_{T \text { win }}(r=0.76$, $p<0.001$ ).

After the values of $T_{\min }$ (depth, temperature, salinity, and $\sigma_{\theta}$ ) were determined from continuous CTD data ( $1 \mathrm{db}$ resolution), we obtained DO, DIC, TA, and nutrients concentrations at the isopycnal surface where $T_{\min }$ occurred by linear interpolation of discrete bottle-sampling data. Note that the values of depth, salinity and $\sigma_{\theta}$ in the $T_{\min }$ layer from continuous CTD data are not necessarily identical to those from discrete bottle sampling. For the isopycnal analysis, the values of DO, DIC, TA, and nutrients on each isopycnal surface from $26.7 \sigma_{\theta}$ to $27.0 \sigma_{\theta}$ were also obtained by linear interpolation of discrete bottle sampling data.

Using CO2SYS software (Pierrot et al., 2006), we calculated the mixing ratio of $\mathrm{CO}_{2}$ by volume in dry air $\left(x \mathrm{CO}_{2}\right)$, $\mathrm{pH}$ (total scale) at the in situ temperature $\left(\mathrm{pH}_{T}^{\text {in situ }}\right)$ and at $25^{\circ} \mathrm{C}\left(\mathrm{pH}_{T}^{25}\right)$, the free hydrogen ion concentration $\left(\left[\mathrm{H}^{+}\right]_{F}\right)$, the carbonate ion concentration $\left(\mathrm{CO}_{3}^{2-}\right)$, and $\Omega$ from mea- sured DIC, TA, phosphate, and silicate values. The carbonate dissociation constants required for the calculation are Mehrbach et al. (1973) as refitted by Dickson and Millero (1987), by using potential temperature, salinity and $0 \mathrm{db}$ pressure in the winter mixed layer $\left(T_{\min }\right.$ layer), and the in situ temperature, salinity and in situ pressure in subsurface waters. We also calculated $\Omega$ with respect to the two minerals forms of $\mathrm{CaCO}_{3}$, aragonite $\left(\Omega_{\text {aragonite }}\right)$ and calcite $\left(\Omega_{\text {calcite }}\right)$, as the ion product of calcium ion $\left(\mathrm{Ca}^{2+}\right)$ and $\mathrm{CO}_{3}^{2-}$ ions:

$\Omega=\left[\mathrm{Ca}^{2+}\right]\left[\mathrm{CO}_{3}^{2-}\right] / K_{\mathrm{sp}}^{\prime}$,

where the square brackets indicate the concentrations of the enclosed species, and K'sp is the thermodynamic solubility product constant for aragonite or calcite (Mucci, 1983). We estimated $\left[\mathrm{Ca}^{2+}\right]$ by assuming the following linear relationship with salinity $(\mathrm{S}):\left[\mathrm{Ca}^{2+}\right]=0.01028 \times \mathrm{S} / 35$ (Millero, 1982). Applying this $\left[\mathrm{Ca}^{2+}\right]$ equation to calculate the $\mathrm{CaCO}_{3}$ saturation horizon will be reasonable, because the notable carbonate-forming biota such as coccolithophore and planktonic foraminifera; pteropods in the western subarctic gyre are living in the surface water (0-100 m) (Hattori et al., 2004, Sagawa et al., 2012, Fujiki et al., 2009, Steinberg et al., 2008), where it was shallower than the $\mathrm{CaCO}_{3}$ saturation horizon of aragonite $(\sim 120 \mathrm{~m})$ (Feely et al., 2004$)$.

\section{Results and Discussion}

\subsection{Acidification in the winter mixed layer}

During the study period, $\mathrm{pH}_{T}^{\text {in situ }}$ and $\mathrm{pH}_{T}^{25}$ in the winter mixed layer significantly decreased at a rate of $-0.0011 \pm 0.0004 \mathrm{yr}^{-1} \quad(p<0.01)$ and $-0.0010 \pm 0.0004 \mathrm{yr}^{-1} \quad(p<0.05)$, respectively (Fig. 3), whereas $\Omega_{\text {aragonite }} \Omega_{\text {calcite }}$ and $\mathrm{CO}_{3}^{2-}$ did not decrease significantly $(p>0.08)$ (not shown). We estimated $\mathrm{pH}_{T}^{\text {in situ }}$, $\Omega_{\text {aragonite, }}, \Omega_{\text {calcite, and } x \mathrm{CO}_{2} \text { in the winter mixed layer from }}$ DIC, TA, phosphate and silicate as describe in Sect. 2.

In the winter mixed layer, $\mathrm{pH}$ decreased more slowly than predicted from oceanic equilibration with the increasing atmospheric $\mathrm{CO}_{2}\left(-0.002 \mathrm{pH}_{T}^{\text {in situ }} \mathrm{yr}^{-1}\right)$, when it was calculated by using the increase in atmospheric $\mathrm{CO}_{2}$ ( $2.1 \mathrm{ppm} \mathrm{yr}^{-1}$ ) in late winter (the beginning of April) from 1997 to 2011 at $44.4^{\circ} \mathrm{N}$ (Conway et al., 2012) and constant $\mathrm{TA}_{\text {win. }}$. In addition, the $\mathrm{pH}$ decreasing rate was slower than the rates that determined in the central North Pacific near Hawaii $\left(-0.0019 \pm 0.0002 \mathrm{pH}_{T}^{\text {in situ }} \mathrm{yr}^{-1}\right.$; Dore et al., 2009), the subtropical western North Pacific along $137^{\circ} \mathrm{E}$ in winter $\left(-0.0015 \pm 0.0002 \mathrm{pH}_{T}^{\text {in situ }} \mathrm{yr}^{-1}\right.$ to $-0.0021 \pm 0.0002$ $\mathrm{pH}_{T}^{\text {in situ }} \mathrm{yr}^{-1}$; Midorikawa et al., 2010), off the south coast of Honshu, Japan $\left(-0.0020 \pm 0.0007 \mathrm{pH}_{T}^{\text {in situ }} \mathrm{yr}^{-1}\right.$; Ishii et al., 2011) and along $152^{\circ} \mathrm{W}$ between Hawaii and Alaska $\left(-0.0017 \mathrm{pH}_{T}^{25} \mathrm{yr}^{-1}\right.$; Byrne et al., 2010).

Because the western subarctic gyre is a source of $\mathrm{CO}_{2}$ to the atmosphere in winter, owing to strong vertical mixing of 

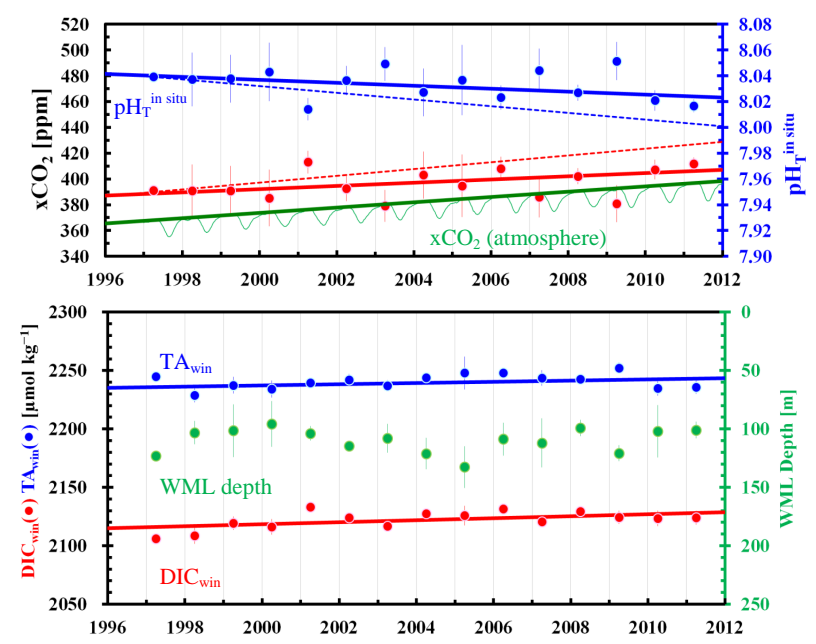

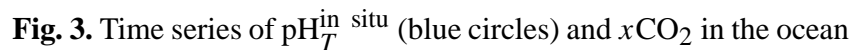
(red circles) and the atmosphere (light green curve) at $44.4^{\circ} \mathrm{N}$ (Conway et al., 2012) (upper panel), and DIC, TA, and depth in the winter mixed layer $\left(\mathrm{DIC}_{\mathrm{win}}, \mathrm{TA}_{\text {win }}\right.$, WML depth) (lower panel). Regression lines for 1997 to 2011 are shown for $\mathrm{pH}_{T}^{\mathrm{in} \text { situ }}$ (blue line, $-0.0011 \pm 0.0004 \mathrm{yr}^{-1}, p<0.01$ ); oceanic $x \mathrm{CO}_{2}$ in winter (red line, $1.2 \pm 0.4 \mathrm{ppm} \mathrm{yr}^{-1}, p<0.005$ ); atmospheric $x \mathrm{CO}_{2}$ in winter (green line, $2.1 \pm 0.0 \mathrm{ppm} \mathrm{yr}^{-1}, p<0.001$ ); $\mathrm{TA}_{\text {win }}$ (blue line, $0.5 \pm 0.2 \mu \mathrm{mol} \mathrm{kg}^{-1} \mathrm{yr}^{-1}, p<0.01$ ); and $\mathrm{DIC}_{\text {win }}$ (red line, $\left.0.9 \pm 0.2 \mu \mathrm{mol} \mathrm{kg}^{-1} \mathrm{yr}^{-1}, p<0.001\right)$. Regression lines shown for the theoretical $\mathrm{pH}_{T}^{\text {in situ }}$ (blue dashed line, $-0.0026 \mathrm{yr}^{-1}$ ) and $x \mathrm{CO}_{2}$ in the ocean (red dashed line, $2.6 \mathrm{ppm} \mathrm{yr}^{-1}$ ) were calculated by using increasing values of DIC and constant TA $\left(2240 \mu \mathrm{mol} \mathrm{kg}^{-1}\right)$.

deep waters rich in DIC, TA and nutrients (e.g., Takahashi et al., 2006), this slower $\mathrm{pH}$ decrease resulted from the combination of the increase of anthropogenic atmospheric $\mathrm{CO}_{2}$, and the wintertime variation in the $\mathrm{CO}_{2}$ emissions caused by the strong vertical mixing. We evaluated the $\mathrm{CO}_{2}$ emission in winter from the difference between atmospheric and oceanic $x \mathrm{CO}_{2}$. The increase of atmospheric $x \mathrm{CO}_{2}$ from 1997 to 2011 $\left(2.1 \pm 0.0 \mathrm{ppm} \mathrm{yr}^{-1}\right)$ in winter is significantly higher than that of oceanic $x \mathrm{CO}_{2}\left(1.2 \pm 0.4 \mathrm{ppm} \mathrm{yr}^{-1}, p<0.005\right)$, calculated from $\mathrm{DIC}_{\text {win }}$ and $\mathrm{TA}_{\text {win }}$, both of which increased significantly during that period $\left(0.9 \pm 0.2 \mu \mathrm{mol} \mathrm{kg} \mathrm{kg}^{-1} \mathrm{yr}^{-1}, p<\right.$ 0.001 , and $0.5 \pm 0.2 \mu \mathrm{mol} \mathrm{kg}{ }^{-1} \mathrm{yr}^{-1}, p<0.01$, respectively) (Fig. 3). These results support the suggestion by Wakita et al. (2010a) that the decadal reduction in $\mathrm{CO}_{2}$ emission in winter is due to the increase of TA.

In $\mathrm{CO}_{2}$ system calculations based on DIC changes at constant TA in the seawater, the oceanic $x \mathrm{CO}_{2}$ increase and the $\mathrm{pH}$ decrease are proportional to the DIC increase. If TA in seawater increases over time, however, then the oceanic $x \mathrm{CO}_{2}$ increasing trend and $\mathrm{pH}$ decreasing rate must be slower than those calculated from the increase of DIC at constant TA. By applying this theoretical framework to the study region and assuming increasing $\mathrm{DIC}_{\text {win }}$ and constant $\mathrm{TA}_{\text {win }}\left(2230 \mu \mathrm{mol} \mathrm{kg}^{-1}\right.$ in 1997), we estimate an oceanic

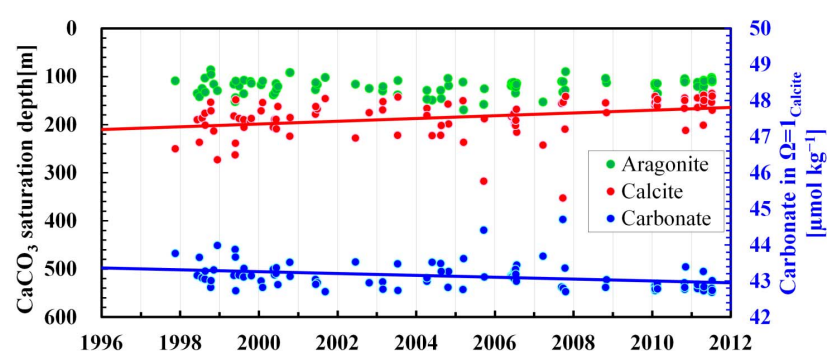

Fig. 4. Time series of the depth of the saturation state of seawater with respect to aragonite (green circles) and calcite $\left(\Omega_{\text {calcite }=1}\right.$; red circles) (left axis), and the concentration of carbonate where $\Omega_{\text {calcite }=1}$ (blue circles) in the western subarctic gyre (right axis). Regression lines for 1997 to 2011 are shown for $\Omega_{\text {calcite }=1}$ (red line, $\left.-2.9 \pm 0.9 \mathrm{myr}^{1}, p<0.001\right)$ and carbonate where $\Omega_{\text {calcite }}=1$ (blue line, $-0.03 \pm 0.01 \mu \mathrm{mol} \mathrm{kg-}{ }^{1} \mathrm{yr}^{-1}, p<0.005$ ).

$x \mathrm{CO}_{2}$ increase and $\mathrm{pH}$ decrease of $2.6 \mathrm{ppm} \mathrm{yr}^{-1}$ and $0.0026 \mathrm{pH}_{T}^{\text {in situ }} \mathrm{yr}^{-1}$, respectively (Fig. 3). However, these rates are twice the actual oceanic $x \mathrm{CO}_{2}$ increase and $\mathrm{pH}$ decrease rates in the winter mixed layer. Thus, the increasing trend of $\mathrm{TA}_{\text {win }}$ inhibits $50 \%$ of $\mathrm{CO}_{2}$ emission and acidification in winter by increasing $\mathrm{DIC}_{\text {win }}$ and suppresses the $\mathrm{CO}_{2}$ emission in the winter mixed layer of western subarctic gyre.

Although the depth of winter mixed layer $\left(T_{\min }\right.$ layer) remained unchanged during the study period (Fig. 3), the variation of $\mathrm{TA}_{\text {win }}$ was moderately but significantly correlated with that of the winter mixed-layer depth $(r=0.37)$. The variation of the winter mixed layer is considered to be linked to atmospheric forcing such as wind stress, which is likely to be greatly affected by climate variation. Thus, $\mathrm{CO}_{2}$ emission and acidification in winter should be affected by climate variation. Further investigation of the climate variations are needed to predict how ocean $\mathrm{CO}_{2}$ emissions and acidification will evolve in this region in the future.

In addition to the increase in $\mathrm{DIC}_{\text {win }}$ and $\mathrm{TA}_{\mathrm{win}}$, $\mathrm{PO}_{4}$ win and $\mathrm{Si}_{\text {win }}$ also significantly increased during the period 1997-2011 $\left(0.012 \pm 0.002 \mu \mathrm{mol} \mathrm{kg}{ }^{-1} \mathrm{yr}^{-1}, p<0.001\right.$, and $0.28 \pm 0.09 \mu \mathrm{mol} \mathrm{kg}^{-1} \mathrm{yr}^{-1}, \quad p<0.05$, respectively), whereas the density of the winter mixed layer $\left(T_{\min }\right.$ layer) significantly decreased $\left(-0.003 \pm 0.002 \mathrm{~kg} \mathrm{~m}^{-3} \mathrm{yr}^{-1}, p<\right.$ 0.05). These results differ from those of Ono et al. (2001, 2002), who reported linear decreasing trends in physical and chemical properties such as salinity, and phosphate in the winter mixed layer in the Oyashio region and the subarctic western North Pacific from 1968 to 1998 as a result of occurrence of surface stratification. More accurate data and longer time series are required to determine the reason for this discrepancy. 

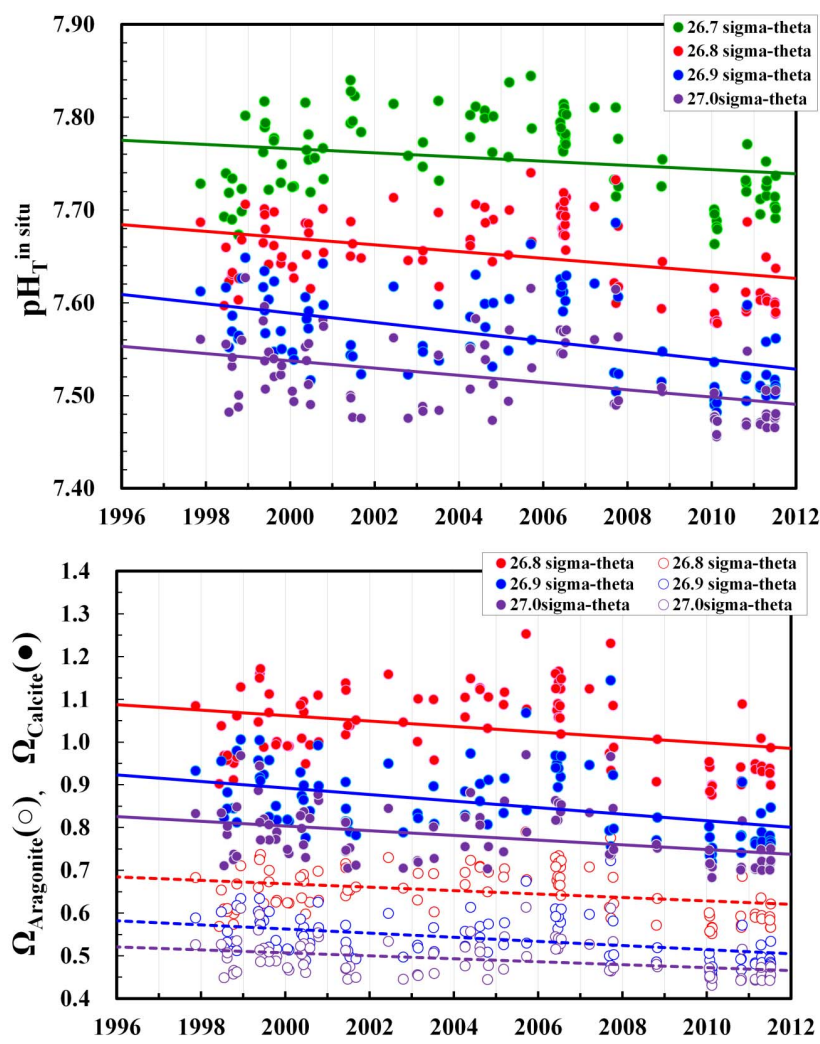

Fig. 5. Time series of $\mathrm{pH}_{T}^{\text {in situ }}$ (upper panel), and the saturation state of seawater with respect to aragonite ( $\Omega_{\text {aragonite }}$, open circles) and calcite ( $\Omega_{\text {calcite }}$, closed circles) (lower panel) in the $26.7 \sigma_{\theta^{-}}$ $27.0 \sigma_{\theta}$ layer. The regression lines for $\mathrm{pH}_{T}^{\text {in situ }}, \Omega_{\text {aragonite, and }}$ $\Omega_{\text {calcite }=1}$ decrease significantly from 1997 to 2011. (see Table 1).

\subsection{Acidification around the $\mathrm{CaCO}_{3}$ saturation horizons}

Below the mixed layer in the western subarctic region, the calcite saturation horizon $\left(\Omega_{\text {calcite }}=1, \sim 185 \mathrm{~m}\right)$ has significantly shoaled at the rate of $2.9 \pm 0.9 \mathrm{~m} \mathrm{yr}^{-1}(p<0.001)$, whereas the aragonite saturation horizon $\left(\Omega_{\text {aragonite }}=1\right)$ has remained constant at about $120 \mathrm{~m}$ depth (Fig. 4). This shoaling rate of $\Omega_{\text {calcite }}=1$ is nearly three times higher than that in the Alaskan gyre between $40^{\circ} \mathrm{N}$ and $50^{\circ} \mathrm{N}$ from 1991 to $2006\left(\sim 1 \mathrm{~m} \mathrm{yr}^{-1}\right)$ (Feely et al., 2012). One cause of upwards migration of the saturation horizon is the decrease of $\mathrm{CO}_{3}^{2-}$ concentration, because oceanic $\mathrm{CO}_{2}$ uptake lowers $\Omega$ due to declining $\mathrm{CO}_{3}^{2-}$. At the depth where $\Omega_{\text {calcite }}=1$, a significant decrease in $\mathrm{CO}_{3}^{2-}$ at a rate of $0.03 \pm 0.01 \mu \mathrm{mol} \mathrm{kg} \mathrm{kg}^{-1} \quad(p<0.005)$ (Fig. 4) has thus caused shoaling of $\Omega_{\text {calcite }}=1$.

Between $26.7 \sigma_{\theta}$ and $27.0 \sigma_{\theta}$, that is, around the depth where $\Omega_{\text {aragonite }}=1\left(\sim 26.8 \sigma_{\theta}\right), \mathrm{pH}$ declined from 1997 to 2011 (Fig. 5, Table 1). The $\mathrm{pH}$ decrease rate in the $26.7-27.0 \sigma_{\theta}$ layer $\left(-0.003\right.$ to $\left.-0.005 \mathrm{yr}^{-1}\right)$ was faster than the acidification rate expected from equilibration with the atmosphere $\left(-0.002 \mathrm{yr}^{-1}\right)$. Similarly, the rate of $\left[\mathrm{H}^{+}\right]_{F}$ increase in the in the 26.7-27.0 $\sigma_{\theta}$ layer $\left(1.0 \times 10^{-10}\right.$ to $2.9 \times 10^{-10} \mathrm{~mol} \mathrm{~kg}^{-1} \mathrm{yr}^{-1}$ ) was faster than the acidity rate expected from equilibration with the atmosphere $\left(0.4 \times 10^{-10} \mathrm{~mol} \mathrm{~kg}^{-1} \mathrm{yr}^{-1}\right)$ (Table 1$)$. Acidity $\left(\left[\mathrm{H}^{+}\right]_{F}\right)$ is on a logarithmic scale as $\mathrm{pH}\left(=-\log _{10}\left[\mathrm{H}^{+}\right]_{F}\right)$. Their rates of $\mathrm{pH}$ decline at various depths actually represented different rates of $\left[\mathrm{H}^{+}\right]_{F}$ accumulation. Decadal change of maximum $\mathrm{pH}$ decline in the subsurface water $(-0.05)$ corresponds to an approximately $10 \%$ increase in $\left[\mathrm{H}^{+}\right]_{F}$. The elevated acidification rate at $26.9 \sigma_{\theta}$ (Table 1) is higher than the previous observed rate in the open North Pacific (at $250 \mathrm{~m}$ depth at Station ALOHA, $-0.003 \mathrm{pH}_{T}^{\text {in situ }} \mathrm{yr}^{-1}$; Dore et al., 2009, and in the upper $500 \mathrm{~m}$ along $152^{\circ} \mathrm{W}$ between Hawaii and Alaska, $-0.004 \mathrm{pH}_{T}^{25} \mathrm{yr}^{-1}$; Byrne et al., 2010), which include both anthropogenic and natural variations.

In addition, $\Omega_{\text {aragonite }}$ and $\Omega_{\text {calcite }}$ in the $26.8-27.0 \sigma_{\theta}$ layer significantly decreased at rates of -0.004 to $-0.005 \mathrm{yr}^{-1}$ and -0.006 to $-0.008 \mathrm{yr}^{-1}$, respectively, during our study period (Fig. 5, Table 1). These subsurface rates are slower than rates in subtropical mode water $\left(-0.034 \Omega_{\text {aragonite }} \mathrm{yr}^{-1}\right)$ or in subsurface waters of the subarctic region (north of $40^{\circ} \mathrm{N}$ ) along $179^{\circ} \mathrm{E}$ and $152^{\circ} \mathrm{W}$ (about $-0.007 \Omega_{\text {aragonite }} \mathrm{yr}^{-1}$ and -0.010 $\Omega_{\text {calcite }} \mathrm{yr}^{-1}$, Murata and Saito, 2012; Feely et al., 2012). In the western subarctic gyre, the significant increase in TA at a rate of $0.5 \pm 0.1 \mu \mathrm{mol} \mathrm{kg}{ }^{-1} \mathrm{yr}^{-1}$ on the $26.9 \sigma_{\theta}$ surface (Table 2) can account for the slower decline in $\Omega$ and $\mathrm{CO}_{3}^{2-}$ concentration in subsurface waters. In fact, the observed decrease rate of $\mathrm{CO}_{3}^{2-}$ on the $26.9 \sigma_{\theta}$ surface $\left(-0.36 \mu \mathrm{mol} \mathrm{kg}{ }^{-1} \mathrm{yr}^{-1}\right)$ is slower than the rate calculated by using increasing DIC and constant TA $\left(-0.49 \mu \mathrm{mol} \mathrm{kg}{ }^{-1} \mathrm{yr}^{-1}\right)$; this calculated rate predicts a faster decline of $\Omega\left(-0.007 \Omega_{\text {aragonite }} \mathrm{yr}^{-1},-0.010\right.$ $\Omega_{\text {calcite }} \mathrm{yr}^{-1}$ ) than the observed declines, which is in good agreement with rates in the subarctic region along $179^{\circ} \mathrm{E}$ and $152^{\circ} \mathrm{W}$ (Murata and Saito, 2012; Feely et al., 2012). Because one component of TA and DIC is $\mathrm{CO}_{3}^{2-}$, increases in TA slow the decrease rates of $\Omega_{\text {aragonite }}$ and $\Omega_{\text {calcite }}$ in intermediate waters.

\subsection{Impact of other properties on the $\mathrm{pH}$ decrease rate on the $26.9 \sigma_{\theta}$ surface}

Because we found that the $\mathrm{pH}$ decrease rate was enhanced between $26.8 \sigma_{\theta}$ and $27.0 \sigma_{\theta}$, we focus on the factors controlling the largest $\mathrm{pH}$ decrease rate, on $26.9 \sigma_{\theta}(-0.0051$ $\mathrm{pH}_{T}^{\text {in situ }} \mathrm{yr}^{-1}$, Table 1), which was at the depth of the temperature maximum (e.g., Wakita et al., 2010a). In this study, we calculated $\mathrm{pH}_{T}^{\text {in situ }}$ from pressure, temperature, salinity, phosphate, silicate, DIC, and TA; therefore, the $\mathrm{pH}$ decrease reflects significant temporal changes in these properties on $26.9 \sigma_{\theta}$ from 1997 to 2011 (Table 2). Therefore, to investigate which properties dominantly controlled $\mathrm{pH}$ changes, we expressed the $\mathrm{pH}$ change (decrease) from 1997 to $2011(\Delta \mathrm{pH})$ 
Table 1. Rates of decrease for $\mathrm{pH}$, free hydrogen ion $\left(\left[\mathrm{H}^{+}\right]_{F}\right)$ and $\Omega$ in the western subarctic gyre from 1997 to 2011.

\begin{tabular}{lcccccc}
\hline Layer & Depth(ave.) $[\mathrm{m}]$ & $\mathrm{pH}_{T}^{\text {in situ }}$ & $\mathrm{pH}_{T}^{25}$ & {$\left[\mathrm{H}^{+}\right]_{F}\left[\mathrm{~mol} \mathrm{~kg}^{-1} \mathrm{yr}^{-1}\right]$} & $\Omega_{\text {Aragonite }}$ & $\Omega_{\text {calcite }}$ \\
\hline $26.7 \sigma_{\theta}$ & $144.0 \pm 13.9$ & $-0.0022 \pm 0.0010$ & $-0.0019 \pm 0.0009$ & $1.0 \pm 0.4 \times 10^{-10}$ & \\
& & $(p<0.05)$ & $(p<0.05)$ & $(p<0.05)$ & \\
$26.8 \sigma_{\theta}$ & $172.4 \pm 19.1$ & $-0.0036 \pm 0.0009$ & $-0.0030 \pm 0.0008$ & $1.8 \pm 0.4 \times 10^{-10}$ & $-0.0040 \pm 0.0012$ & $-0.0064 \pm 0.0020$ \\
& & $(p<0.0001)$ & $(p<0.0001)$ & $(p<0.005)$ & $(p<0.005)$ & $(p<0.005)$ \\
$26.9 \sigma_{\theta}$ & $215.3 \pm 27.9$ & $-0.005 \pm 0.0010$ & $-0.0042 \pm 0.0009$ & $2.9 \pm 0.6 \times 10^{-10}$ & $-0.0048 \pm 0.0011$ & $-0.0077 \pm 0.0018$ \\
& & $(p<0.0001)$ & $(p<0.0001)$ & $(p<0.0001)$ & $(p<0.0001)$ & $(p<0.0001)$ \\
$27.0 \sigma_{\theta}$ & $279.8 \pm 33.3$ & $-0.0039 \pm 0.0009$ & $-0.0032 \pm 0.0008$ & $2.5 \pm 0.6 \times 10^{-10}$ & $-0.0035 \pm 0.0009$ & $-0.0055 \pm 0.0015$ \\
& & $(p<0.0001)$ & $(p<0.0001)$ & $(p<0.0005)$ & $(p<0.0005)$ & $(p<0.0005)$ \\
\hline
\end{tabular}

Table 2. Rates of change in DIC and other parameters on the $26.9 \sigma_{\theta}$ surface in the western subarctic gyre. Error values are the standard error of the slope of the linear regression.

\begin{tabular}{lrrr}
\hline Parameters & Rates [units] & $p$ value \\
\hline Pressure & $-1.72 \pm 0.58$ & {$\left[\mathrm{db} \mathrm{yr}^{-1}\right]$} & $<0.005$ \\
Temperature & $0.025 \pm 0.005$ & {$\left[{ }^{\circ} \mathrm{Cyr}^{-1}\right]$} & $<0.001$ \\
Salinity & $0.0027 \pm 0.0006$ & {$\left[\mathrm{yr}^{-1}\right]$} & $<0.001$ \\
Phosphate & $0.011 \pm 0.002$ & {$\left[\mu \mathrm{mol} \mathrm{kg}{ }^{-1} \mathrm{yr}^{-1}\right]$} & $<0.001$ \\
Silicate & $0.23 \pm 0.06$ & {$\left[\mu \mathrm{mol} \mathrm{kg}{ }^{-1} \mathrm{yr}^{-1}\right]$} & $<0.001$ \\
TA & $0.5 \pm 0.1$ & {$\left[\mu \mathrm{molkg}^{-1} \mathrm{yr}^{-1}\right]$} & $<0.001$ \\
DIC & $2.0 \pm 0.3$ & {$\left[\mu \mathrm{mol} \mathrm{kg}^{-1} \mathrm{yr}^{-1}\right]$} & $<0.001$ \\
\hline
\end{tabular}

as the sum of the change in each property, as follows:

$$
\begin{aligned}
\Delta \mathrm{pH} & =(\partial \mathrm{pH} / \partial \text { Press }) \Delta \text { Press }+(\partial \mathrm{pH} / \partial T) \Delta T \\
& +(\partial \mathrm{pH} / \partial S) \Delta S+\left(\partial \mathrm{pH} / \partial \mathrm{PO}_{4}\right) \Delta \mathrm{PO}_{4} \\
& +(\partial \mathrm{pH} / \partial \mathrm{Si}) \Delta \mathrm{Si}+(\partial \mathrm{pH} / \partial \mathrm{DIC}) \Delta \mathrm{DIC} \\
& +(\partial \mathrm{pH} / \partial \mathrm{TA}) \Delta \mathrm{TA}
\end{aligned}
$$

where Press, $T$, and $S$ are pressure (unit: db), temperature (unit: ${ }^{\circ} \mathrm{C}$ ), and salinity, respectively. $\Delta$ Press, $\Delta T, \Delta S$, $\Delta \mathrm{PO}_{4}, \Delta \mathrm{Si}, \Delta \mathrm{DIC}$, and $\Delta \mathrm{TA}$ show the changes in Press, $T$, $S, \mathrm{PO}_{4}, \mathrm{Si}, \mathrm{DIC}$, and TA, respectively. In the actual calculation, we evaluated the rate of $\mathrm{pH}$ change by allowing one parameter to vary while using mean values for the other parameters. For example, we estimated the contribution of $\triangle \mathrm{DIC}$ to $\Delta \mathrm{pH}((\partial \mathrm{pH} / \partial \mathrm{DIC}) \Delta \mathrm{DIC})$ by calculating $\Delta \mathrm{pH}$ using the increasing values of DIC from 1997 to 2011 and mean values for the other parameters $\left(-0.0064 \pm 0.0010 \mathrm{pH}_{T}^{\text {in situ }} \mathrm{yr}^{-1}\right.$, $p<0.001)$ and then computed the impact of $\Delta \mathrm{DIC}$ on $\Delta \mathrm{pH}$ to be $127 \%$ by dividing the $\triangle \mathrm{DIC}$ contribution by the rate of $\mathrm{pH}$ decline on $26.9 \sigma_{\theta}(-0.0064 /-0.0051 \times 100)($ Fig. 6).

The results of these calculations show that $\triangle \mathrm{DIC}$ had the largest negative impact on $\Delta \mathrm{pH}(127 \pm 32 \%)$ and $\Delta \mathrm{TA}$ had the largest positive impact $(-34 \pm 8 \%)$ (Fig. 6). The increases in DIC and in temperature ( $\Delta T$ impact, $8 \pm 2 \%$ ) over time enhanced the rate of acidification. The contribution of $\Delta \mathrm{T}\left(-0.0004 \pm 0.0001 \mathrm{pH}_{T}^{\text {in situ }} \mathrm{yr}^{-1}\right)$ was equivalent

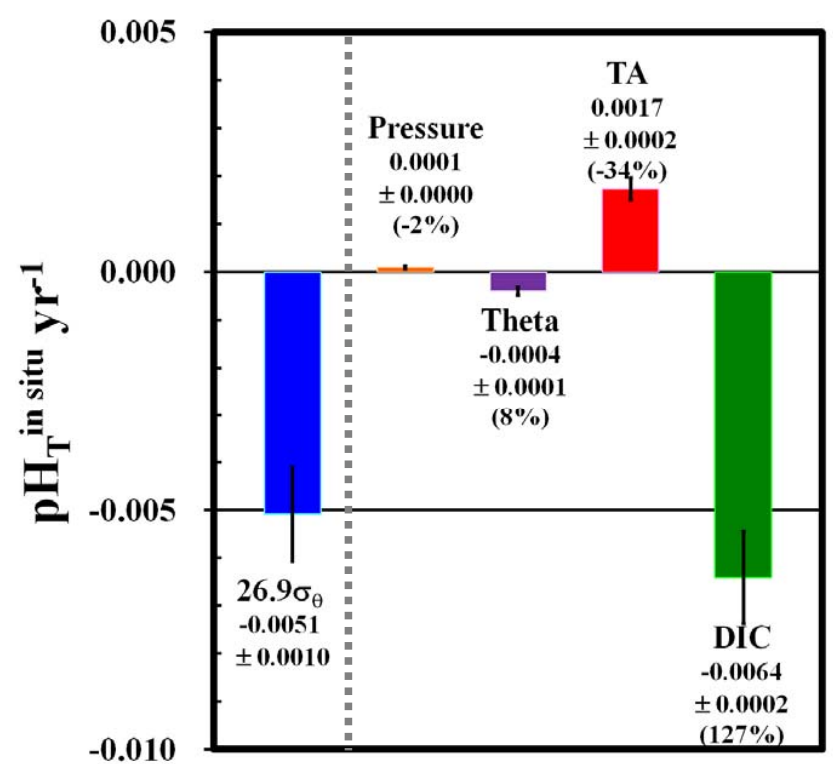

Fig. 6. Contributions of various parameters to the $\mathrm{pH}$ decrease on the $26.9 \sigma_{\theta}$ surface. The percentages in parentheses indicate the relative contribution of each parameter to the $\mathrm{pH}$ decrease ($\left.0.0051 \pm 0.0010 \mathrm{pH}_{T}^{\text {in situ }} \mathrm{yr}^{-1}\right)$.

to the difference between the in situ and fixed temperature $\mathrm{pH}$ trends (Table 1). $\Delta \mathrm{TA}$ and shoaling of the $26.9 \sigma_{\theta}$ isopycnal surface ( $\Delta$ Press, $-2 \pm 1 \%$ ) inhibited the $\mathrm{pH}$ decrease. The impacts of $\Delta \mathrm{S}, \Delta \mathrm{PO}_{4}$, and $\Delta \mathrm{Si}$ were negligibly small $(\sim 0 \%)$. In addition, nDIC, which normalized to a salinity of 35 , in the $26.9 \sigma_{\theta}$ surface significantly increased at rate of $1.8 \pm 0.3 \mu \mathrm{mol} \mathrm{kg} \mathrm{gr}^{-1}(p<0.001)$. This value is consistent with DIC increase at the same isopycnal surface (Table 2, Fig. 7). Thus, the lack of a $\Delta \mathrm{S}$ contribution means that the influence of local changes evaporation and precipitation was very low; therefore, there is no need to use salinitynormalized values of DIC, TA, and nutrients to correct for such an effect. 

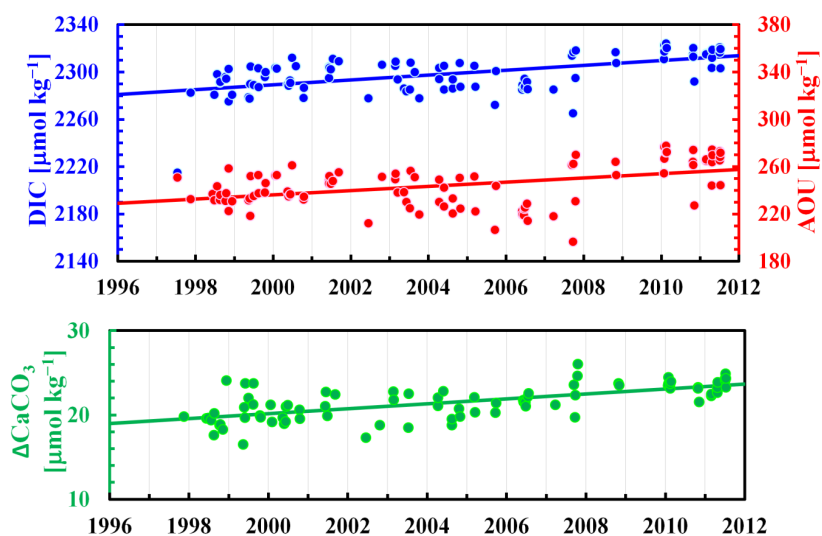

Fig. 7. Time series of DIC (blue circles) and AOU (red circles) (upper panel) and $\Delta \mathrm{CaCO}_{3}$ (green circles) (lower panel) on the $26.9 \sigma_{\theta}$ surface. Regression lines for 1997 to 2011 are shown for DIC (blue line, $2.0 \pm 0.3 \mu \mathrm{mol} \mathrm{kg}^{-1} \mathrm{yr}^{-1}, p<0.001$ ), AOU (red line, $1.8 \pm 0.4 \mu \mathrm{mol} \mathrm{kg}^{-1} \mathrm{yr}^{-1}, p<0.001$ ) and $\Delta \mathrm{CaCO}_{3}$ (green line, $\left.0.3 \pm 0.1 \mu \mathrm{mol} \mathrm{kg}^{-1} \mathrm{yr}^{-1}, p<0.001\right)$.

\subsection{Contribution of the DIC increase to enhanced acidification}

As shown in Sect. 3.3, $\Delta$ DIC dominantly accounted for the faster $\mathrm{pH}$ decline on $26.9 \sigma_{\theta}$. We investigated factors affecting the DIC increase rate at this depth $\left(2.0 \pm 0.3 \mu \mathrm{mol} \mathrm{kg}{ }^{-1} \mathrm{yr}^{-1}\right.$, $p<0.001$ ) (Fig. 7, Table 2).

Changes of DIC along an isopycnal surface of subsurface water are controlled by the gas exchange of $\mathrm{CO}_{2}$ at the air-sea interface $\left(\mathrm{DIC}_{\text {air-sea }}\right)$, the decomposition of organic matter $\left(\mathrm{DIC}_{\mathrm{org}}\right)$ and the dissolution of calcium carbonate $\left(\mathrm{DIC}_{\mathrm{CaCO}_{3}}\right)$. We can express the observed DIC change $\left(\Delta \mathrm{DIC}_{\mathrm{obs}}\right)$, as follows (e.g., Sabine et al., 2002):

$\Delta \mathrm{DIC}_{\mathrm{obs}}=\Delta \mathrm{DIC}_{\text {air-sea }}+\Delta \mathrm{DIC}_{\mathrm{org}}+\Delta \mathrm{DIC}_{\mathrm{CaCO}_{3}}$

$\Delta \mathrm{DIC}_{\text {org }}$ is calculated as following,

$\Delta \mathrm{DIC}_{\text {org }}=\left(\mathrm{C}_{\mathrm{org}} /-\mathrm{O}_{2}\right) \Delta \mathrm{AOU}_{\mathrm{obs}}$,

where $\triangle \mathrm{AOU}_{\mathrm{obs}}$ is the observed rate of the $\mathrm{AOU}$ change. AOU significantly increased at a rate of $1.8 \pm 0.4 \mu \mathrm{mol} \mathrm{kg}^{-1} \mathrm{yr}^{-1} \quad(p<0.0001)$ (Fig. 7). $\Delta \mathrm{DIC}_{\mathrm{org}}$ was calculated to be $1.2 \pm 0.3 \mu \mathrm{mol} \mathrm{kg} \mathrm{kg}^{-1} \mathrm{yr}^{-1}$.

The dissolution of $\mathrm{CaCO}_{3}$ neutralizes $\mathrm{CO}_{2}$ taken up by seawater and increases TA via the reaction $\left(\mathrm{CaCO}_{3}+\mathrm{CO}_{2}\right.$ $\left.+\mathrm{H}_{2} \mathrm{O} \rightarrow 2 \mathrm{HCO}_{3}^{-}+\mathrm{Ca}^{2+}\right)$. We evaluated $\Delta \mathrm{DIC}_{\mathrm{CaCO}_{3}}$ as $\triangle \mathrm{CaCO}_{3}$ (Feely et al., 2004):

$$
\begin{aligned}
\Delta \mathrm{DIC}_{\mathrm{CaCO}_{3}} & =\Delta \mathrm{CaCO}_{3}=0.5\left(\mathrm{TA}-\mathrm{TA}^{\circ}\right) \\
& +0.63(16 / 170 \mathrm{AOU}),
\end{aligned}
$$

where $\mathrm{TA}^{\circ}$ is preformed $\mathrm{TA}$, calculated by using the equation of Sabine et al. (2002). $\triangle \mathrm{DIC}_{\mathrm{CaCO}_{3}}$ significantly increased at a rate of $0.3 \pm 0.1 \mu \mathrm{mol} \mathrm{kg}{ }^{-1} \mathrm{yr}^{-1}(p<0.0001)$ (Fig. 7).
This result, which is consistent with the 50\% increase of TA on the same isopycnal surface (Table 2), suggests that the dissolution of $\mathrm{CaCO}_{3}$ particles increased as a result of the enhanced acidification caused by anthropogenic $\mathrm{CO}_{2}$ and the AOU increase below the depth of $\Omega=1(120-200 \mathrm{~m})$; these saturation depths are shallower than the saturation depth in the open North Pacific (Feely et al., 2004).

By subtracting $\triangle \mathrm{DIC}_{\text {org }}$ and $\triangle \mathrm{DIC}_{\mathrm{CaCO}_{3}}$ from $\triangle \mathrm{DIC}$ obs according to Eq. (6), we estimated $\Delta \mathrm{DIC}_{\text {air-sea }}$ to be $0.5 \pm 0.4 \mu \mathrm{mol} \mathrm{kg}^{-1} \mathrm{yr}^{-1}$. This rate is indistinguishable from that expected under condition of seawater/atmosphere equilibration $\left(0.7 \mu \mathrm{mol} \mathrm{kg}{ }^{-1} \mathrm{yr}^{-1}\right)$, when calculated from the increase of atmospheric $\mathrm{CO}_{2}\left(2.1 \mathrm{ppm} \mathrm{yr}^{-1}\right)$ from 1997 to 2011 at $44.4^{\circ} \mathrm{N}$ (Conway et al., 2012) and constant $\mathrm{TA}_{\text {win }}$. We assumed that $\triangle \mathrm{DIC}_{\text {air-sea }}$ indicates the DIC increase due to the uptake of anthropogenic $\mathrm{CO}_{2}\left(\Delta \mathrm{DIC}_{\mathrm{anth}}\right) . \mathrm{DIC}_{\mathrm{air}-\text { sea }}$ includes the DIC content of waters in equilibrium with preindustrial atmospheric $\mathrm{CO}_{2}(280 \mu \mathrm{atm})\left(\mathrm{DIC}_{\mathrm{eq} 280}\right)$ and the DIC content due to the of air-sea disequilibrium $\mathrm{CO}_{2}$ effect $\left(\mathrm{DIC}_{\mathrm{diseq}}\right)$. DIC $\mathrm{C}_{\mathrm{eq} 280}$ remains constant over time and its trend can be cancelled out. We also can neglect temporal change of $\mathrm{DIC}_{\text {diseq }}$ on $26.9 \sigma_{\theta}$, i.e., $\Delta \mathrm{DIC}_{\text {diseq }}=0$, because $\Delta$ DIC $_{\text {air-sea }}$ on $26.9 \sigma_{\theta}\left(0.5 \mu \mathrm{mol} \mathrm{kg}{ }^{-1} \mathrm{yr}^{-1}\right)$ was lower than the $\mathrm{DIC}_{\text {win }}$ increase $\left(0.9 \mu \mathrm{mol} \mathrm{kg}{ }^{-1} \mathrm{yr}^{-1}\right)$ which was affected by the increase of anthropogenic $\mathrm{CO}_{2}$ and the reduction of $\mathrm{CO}_{2}$ emission in winter (Wakita et al., 2010a).

The contribution of $\triangle \mathrm{DIC}\left(2.0 \pm 0.3 \mu \mathrm{mol} \mathrm{kg} \mathrm{kg}^{-1}\right)$ is thus accounted for by $\Delta \mathrm{DIC}_{\text {org }}(60 \pm 17 \%), \Delta \mathrm{DIC}_{\text {anth }}$ $(25 \pm 22 \%)$ and $\Delta \mathrm{DIC}_{\mathrm{CaCO}_{3}}(15 \pm 5 \%)$. Acidification of intermediate water in the western subarctic gyre ($0.0051 \pm 0.0010 \mathrm{pH}_{T}^{\text {in situ }} \mathrm{yr}^{-1}$ ) was enhanced by increases in the decomposition of organic matter $(75 \pm 29 \%)$ and, in the anthropogenic $\mathrm{CO}_{2}$ uptake $(31 \pm 29 \%)$, by the increased dissolution of $\mathrm{CaCO}_{3}$ particles $(19 \pm 8 \%)$ and by water temperature warming $(8 \pm 2 \%)$, and it was inhibited by the TA increase $(-34 \pm 8 \%)$ and the shoaling of the isopycnal surface $(-2 \pm 1 \%)$. Because the $\triangle \mathrm{DIC}_{\mathrm{CaCO}_{3}}$ is equivalent to $\sim 50 \%$ increase of TA, the enhanced contribution of the increased dissolution of $\mathrm{CaCO}_{3}$ particles to faster $\mathrm{pH}$ decline could offset the inhibited contribution of TA increase. Non-anthropogenic $\mathrm{CO}_{2}$ factors correspond to $\triangle \mathrm{DIC}_{\text {org }}$ evaluated from $\mathrm{AOU}$ increase and must also contribute to the $\mathrm{pH}$ decrease, independently of the uptake of anthropogenic $\mathrm{CO}_{2}$. The non-anthropogenic $\mathrm{CO}_{2}$ contribution dominantly accounted for the enhanced acidification of intermediate water rather than anthropogenic $\mathrm{CO}_{2}$ uptake, but our value might be an overestimate. This is because the long-term trends and bi-decadal oscillations of AOU in subsurface waters in the northwestern subarctic $\mathrm{Pa}$ cific Ocean have been reported (ex., Ono et al., 2001; Osafune and Yasuda, 2006; Watanabe et al., 2008, Takatani et al., 2012). In our data, collected during 1997-2011, AOU varies on a shorter than bi-decadal cycle and the AOU increase on $26.9 \sigma_{\theta}\left(1.8 \pm 0.4 \mu \mathrm{mol} \mathrm{kg}^{-1} \mathrm{yr}^{-1}\right)$ was twice that from 1968 to 1998 in the Oyashio region near the western 
subarctic gyre $\left(0.8 \pm 0.3 \mu \mathrm{mol} \mathrm{kg}{ }^{-1} \mathrm{yr}^{-1}\right)$ (Ono et al., 2001). Considering this context and the stoichiometric ratio of carbon to oxygen from organic matter decomposition, the minimum possible contribution of non-anthropogenic $\mathrm{CO}_{2}$ $\left(0.8 \times 117 / 170=0.55 \mu \mathrm{mol} \mathrm{kg} \mathrm{yr}^{-1}\right)$ is the same as the anthropogenic $\mathrm{CO}_{2}$ uptake $\left(0.5 \pm 0.4 \mu \mathrm{mol} \mathrm{kg}{ }^{-1} \mathrm{yr}^{-1}\right)$ in the western subarctic gyre, which is the same the uptake rate in intermediate water along $152^{\circ} \mathrm{W}$ during 1991-2006 (Byrne et al., 2010) and $179^{\circ} \mathrm{E}$ during 1993-2007 (Murata and Saito, 2012). Thus, the enhanced acidification (pH decrease) between 200 and $300 \mathrm{~m}$ depth in this region reflects both anthropogenic $\mathrm{CO}_{2}$ and non-anthropogenic $\mathrm{CO}_{2}$ contribution, which will not affect the spatial distributions of acidification rates (Murata and Saito, 2012).

Temporal changes of AOU in the subsurface waters thus reflect those of both physical processes such as ocean circulation and ventilation, and biological processes such as the remineralization of organic matter. At first, we examine the stoichiometric ratios of phosphorus and nitrogen to oxygen during the decomposition of organic matter $\left(\left(\mathrm{P} /-\mathrm{O}_{2}\right),\left(\mathrm{N} /-\mathrm{O}_{2}\right)\right)$ in the $26.9 \sigma_{\theta}$ surface, because phosphate, nitrate, AOU increased significantly over the period of observation $\left(0.011 \pm 0.002 \mu \mathrm{mol} \mathrm{kg}{ }^{-1} \mathrm{yr}^{-1}\right.$, $p<0.0001$, and $0.24 \pm 0.04 \mu \mathrm{mol} \mathrm{kg}-1 \mathrm{yr}^{-1}, p<0.0001$, $1.8 \pm 0.4 \mu \mathrm{mol} \mathrm{kg}^{-1} \mathrm{yr}^{-1}, p<0.0001$ respectively). Based on each increase rate, $\left(\mathrm{P} /-\mathrm{O}_{2}\right)$ and $\left(\mathrm{N} /-\mathrm{O}_{2}\right)$ are calculated to be $171 \pm 38(0.011 / 1.8)$ and $23 \pm 4(0.24 / 1.8)$, which are nearly consistent with previous values $(170 \pm 10,16 \pm 1$, Anderson and Sarmiento, 1994). This result indicates that remineralization of organic matter have remained constant. Thus, the increases of AOU on $26.9 \sigma_{\theta}$ will be caused by physical processes such as the increase of residence time in the intermediate water.

The changes of physical processes will be dominant in causing the AOU changes (e.g., Deutsch et al., 2005, Mecking et al., 2008). The temporal variations of $\mathrm{AOU}$ in the $26.7-27.2 \sigma_{\theta}$ layer in the Oyashio region and a wintertime wind stress curl anomaly in this region are negatively and positively correlated, respectively, with the bi-decadal component of the North Pacific Index (Ono et al., 2001; Ishi and Hanawa, 2005). Because AOU was positively correlated with DIC in the subsurface waters of the western subarctic gyre $(r=0.99)$ due to the decomposition of organic matter, DIC might also exhibit a bi-decadal oscillation. In addition, in this region, the weakening of the overturning circulation due to reduced winds since the 1970 s causes DIC to increase by AOU increase rather than anthropogenic $\mathrm{CO}_{2}$ uptake (Feely et al., 2012). Considering that minimum estimates of anthropogenic $\mathrm{CO}_{2}$ and non-anthropogenic $\mathrm{CO}_{2}$ contributions are of similar magnitude, at least half of the $\mathrm{pH}$ decrease rate in the intermediate waters may be related to atmospheric forcing change related to the climate variations.

\section{Conclusions}

Anthropogenic $\mathrm{CO}_{2}$ uptake and natural variability due to temporal changes in physical and biogeochemical processes affect acidification in the both the winter mixed layer and intermediate waters in the western subarctic gyre. In the winter mixed layer, $\mathrm{pH}$ decreased at $-0.0011 \pm 0.0004 \mathrm{pH}_{T}^{\text {in situ }} \mathrm{yr}^{-1}$ from 1997 to 2011, whereas $\Omega_{\text {aragonite }}, \Omega_{\text {calcite, and } \mathrm{CO}_{3}^{2-} \text { re- }}$ mained unchanged. This decreasing trend of $\mathrm{pH}$ was slower than that predicted based on equilibration of atmospheric $\mathrm{CO}_{2}$ with the seawater $\left(-0.002 \mathrm{pH}_{T}^{\text {in situ }} \mathrm{yr}^{-1}\right)$ and slower than decrease rates in other regions (Dore et al., 2009; Midorikawa et al., 2010; Ishii et al., 2011; Byrne et al., 2010). We attribute this lower rate to a reduction of $\mathrm{CO}_{2}$ emission in winter caused by increased $\mathrm{TA}_{\text {win. }}$. Although the correlation of $\mathrm{TA}_{\text {win }}$ with the depth of the winter mixed layer $(r=0.37)$ is quite small, it is significant.

Below the mixed layer, the calcite saturation horizon $\left(\Omega_{\text {calcite }}=1\right)$ has shoaled at $2.9 \pm 0.9 \mathrm{~m} \mathrm{yr}^{-1}$ because of declines in $\mathrm{CO}_{3}^{2-}\left(-0.03 \pm 0.01 \mu \mathrm{mol} \mathrm{kg} \mathrm{yr}^{-1}\right)$, and the acidification rate at $\sim 200 \mathrm{~m}$ depth $\left(-0.0051 \pm 0.0010 \mathrm{pH}_{T}^{\text {in situ }}\right.$ $\mathrm{yr}^{-1}$ ) was larger than ever reported in the open North Pacific during the study period (e.g., Dore et al., 2009; Byrne et al., 2010). The enhanced $\mathrm{pH}$ decline reflected not only the uptake of anthropogenic $\mathrm{CO}_{2}$ but also natural variability evaluated from the increase in AOU, which suggests that the dissolution of $\mathrm{CaCO}_{3}$ particles increased. The TA increase due to this increase of $\mathrm{CaCO}_{3}$ dissolution inhibited the decrease rate of $\Omega_{\text {aragonite }}$ and $\Omega_{\text {calcite }}$ in the intermediate water $(-0.004$ to $-0.005 \mathrm{yr}^{-1}$ and -0.006 to $-0.008 \mathrm{yr}^{-1}$ ).

The acidification observed at K2 and KNOT will affect carbonate forming biota in the surface and subsurface waters of the western subarctic region. However, our detection of the $\mathrm{pH}$ decrease in the winter mixed layer is not enough to clarify the impact of acidification on biological production and ecosystems in the entire western subarctic gyre. Therefore, the temporal variation of the $\mathrm{pH}$ in the mixed layer needs to be evaluated by using more accurate data from a longer time series. Moreover, the $\mathrm{CO}_{2}$ efflux from the winter mixed layer and the enhanced $\mathrm{pH}$ decrease in the subsurface waters must be related to changes in atmospheric forcing as well as the anthropogenic increase in atmospheric $\mathrm{CO}_{2}$. Additional time-series data are required to investigate the relationships among temporal variability of $\mathrm{pH}$, oceanic physical processes, and atmospheric forcing/climate index.

Acknowledgements. We acknowledge the staff of Mutsu Institute for Oceanography, the Japan Agency for Marine-Earth Science and Technology (JAMSTEC) and the captains and crews of the R/V Mirai for their kind cooperation in the collection of samples and hydrographic measurements during the 2010-2011 cruises. For their valuable comments and discussion, we thank T. Saino, Y. Mino, H. Uchida, and N. Harada of JAMSTEC; M. Aoyama of the Meteorological Research Institute; T. Tanaka of the Japan Atomic Energy Agency; T. Ono of the Fisheries Research Agency; 
and Y. W. Watanabe of Hokkaido University. We also thank those staff members of Marine Works Japan, Ltd., and Global Ocean Development Inc. who worked as marine technicians onboard the R/V Mirai. This work was partly supported by the Ministry of Education, Culture, Sports, Science and Technology (MEXT), Grant-in-Aid for Scientific Research on Innovative Areas (25106709). Finally, we also express our deep thanks to two anonymous reviewers who gave us many useful comments.

Edited by: K. Denman

\section{References}

Anderson, L. A. and Sarmiento, J. L.: Redfield ratios of remineralization determined by nutrient data analysis, Global Biogeochem. Cycles, 8, 65-80, doi: doi:10.1029/93GB03318 1994.

Bindoff, N. L., Willebrand, J., Artale, V., Cazenave, A., Gregory, J., Gulev, S., Hanawa, K., Le Quéré, C., Levitus, S., Nojiri, Y., Shum, C. K., Talley, L. D., and Unnikrishnan, A.: Observations: Oceanic Climate Change and Sea Level, in: Climate Change 2007: The Physical Science Basis. Contribution of Working Group I to the Fourth Assessment Report of the Intergovernmental Panel on Climate Change, edited by: Solomon, S., Qin, D., Manning, M., Chen, Z., Marquis, M., Averyt, K. B., Tignor M., and Miller, H. L., Cambridge University Press, Cambridge, United Kingdom and New York, NY, USA, 2007.

Byrne, R. H., Mecking, S., Feely, R. A., and Liu, X.: Direct observations of basin-wide acidification of the North Pacific Ocean, Geophys. Res. Lett., 37, L02601, doi:10.1029/2009GL040999, 2010.

Conway, T. J., Masarie, K. A., Lang, P. M., and Tans, P. P.: NOAA Greenhouse Gas Reference from Atmospheric Carbon Dioxide Dry Air Mole Fractions from the NOAA ESRL Carbon Cycle Cooperative Global Air Sampling Network Path: ftp://ftp.cmdl. noaa.gov/ccg/co2/flask/, 2012.

de Boyer Montégut, C., Madec, G., Fischer, A. S., Lazar, A., and Iudicone, D.: Mixed layer depth over the global ocean: An examination of profile data and a profile-based climatology, J. Geophys. Res., 109, C12003, doi:10.1029/2004JC002378, 2004.

Deutsch, C., Emerson, S., and Thompson, L.: Fingerprints of climate change in North Pacific oxygen, Geophys. Res. Lett., 32, L16604, doi:10.1029/2005GL023190, 2005.

Dickson, A. G. and Millero, F. J.: A comparison of the equilibrium constants for the dissociation of carbonic acid in seawater media, Deep-Sea Res Pt. A, 34, 1733-1743, doi:10.1016/01980149(87)90021-5 1987.

Doney, S. C., Fabry, V. J., Feely, R. A., and Kleypas, J. A.: Ocean acidification: the other $\mathrm{CO}_{2}$ problem, Ann. Rev. Mar. Sci., 1, 169-192, doi:10.1146/annurev.marine.010908.163834, 2009.

Dore, J. E., Lukas, R., Sadler, D. W., Church, M. J., and Karl, D. M.: Physical and biogeochemical modulation of ocean acidification in the central North Pacific, P. Natl. Acad. Sci., 106, 1223512240, doi:10.1073/pnas.0906044106, 2009.

Feely, R. A., and Chen, C. T.: The effect of excess $\mathrm{CO}_{2}$ on the calculated calcite and aragonite saturation horizons in the northeast Pacific, Geophys. Res. Lett., 9, 1294-1297, doi:10.1029/GL009i011p01294, 1982.
Feely, R. A., Sabine, C. L., Lee, K., Berelson, W., Kleypas, J., Fabry, V. J., and Millero, F. J.,: Impact of anthropogenic $\mathrm{CO}_{2}$ on the $\mathrm{CaCO}_{3}$ system in the oceans, Science, 305, 362-366, doi:10.1126/science.109732926, 2004.

Feely, R. A., Sabine, C. L., Byrne, R. H., Millero, F. J., Dickson, A. G., Wanninkhof, R., Murata, A., and Miller L. A.: Decadal changes in the aragonite and calcite saturation state of the Pacific Ocean, Global Biogeochem. Cycles, GB3001, doi:10.1029/2011GB004157, 2012.

Fujiki, T., Matsumoto, K., Honda, M. C., Kawakami, H., and Watanabe, S.: Phytoplankton composition in the subarctic North Pacific during autumn 2005. J. Plankton Res., 31, 179-191, doi:10.1093/plankt/fbn108, 2009.

Fukasawa, M., Kawano, T., Murata, A., Uchida, H., and Doi, T.: Carbon Dioxide, Hydrographic, and Chemical Data Obtained During the R/V Mirai Repeat Hydrography Cruise in the Pacific Ocean: CLIVAR $\mathrm{CO}_{2}$ Section P14_2007 (8 October-26 December 2007), available at: http://cdiac. ornl.gov/ftp/oceans/CLIVAR/P14_2007.data, Carbon Dioxide Information Analysis Center, Oak Ridge National Laboratory, US Department of Energy, Oak Ridge, Tennessee, doi:10.3334/CDIAC/otg.CLIVAR_P14_2007, 2008.

Guinotte, J. M., Orr, J., Cairns, S., Freiwald, A., Morgan, L., and George, R.: Will human-induced changes in seawater chemistry alter the distribution of deep-sea scleractinian corals?, Front. Ecol. Environ, 4, 141-146, doi:10.1890/15409295(2006)004[0141:WHCISC]2.0.CO;2, 2006.

Hattori, H., M. Koike, K. Tashikawa, H. Saito, and K. Nagasawa.: Spatial variability of living coccolithophore distribution in the western subarctic Pacific and western Bering sea, J. Oceanogr., 60, 505-515, doi:10.1023/B:JOCE.0000038063.81738.ab, 2004.

Hosoda, S., Ohira, T., Sato, K., and Suga, T.: Improved description of global mixed-layer depth using Argo profiling floats, J. Oceanogr., 66, 773-787, doi:10.1007/s10872-010-0063-3, 2010.

Ishi, Y. and Hanawa, K.: Large-scale variabilities of wintertime wind stress curl field in the North Pacific and their relation to atmosphere teleconnection patterns, Geophys. Res. Lett., 32, L10607, doi:10.1029/2004GL022330, 2005.

Ishii, M., Kosugi, N., Sasano, D., Saito, S., Midorikawa, T., and Inoue, H. Y.: Ocean acidification off the south coast of Japan: A result from time series observations of $\mathrm{CO}_{2}$ parameters from 1994 to 2008, J. Geophys. Res.-Ocean., 116, C06022, doi:10.1029/2010JC006831, 2011.

Mecking, S., Langdon, C., Feely, R. A., Sabine, C. L., Deutsch, C. A., and Min, D.-H.: Climate variability in the North Pacific thermocline diagnosed from oxygen measurements: An update based on the U.S. CLIVAR/CO 2 Repeat Hydrography cruises, Global Biogeochem. Cycles, 22, GB3015, doi:10.1029/2007GB003101, 2008.

Mehrbach, C., Culberson, C. H., Hawley, J. E., and Pytkowicz, R. M.: Measurement of the apparent dissociation constants of carbonic acid in seawater at atmospheric pressure, Limnol. Oceanogr., 18, 897-907, doi:10.4319/lo.1973.18.6.0897, 1973.

Midorikawa, T., Ishii, M., Saito, S., Sasano, D., Kosugi, N., Motoi, T., Kamiya, H., Nakadate, A., Nemoto, K., and Inoue, H. Y.: Decreasing $\mathrm{pH}$ trend estimated from 25-yr time series of carbonate parameters in the western North Pacific, Tellus B, 62, 649-659, doi:10.1111/j.1600-0889.2010.00474.x, 2010. 
Millero, F. J.: The thermodynamics of seawater at one atmosphere, Ocean Sci. Eng., 7, 403-460, doi:10.1016/0016-7037(94)00354O, 1982 .

Mucci, A.: The solubility of calcite and aragonite in sea water at various salinities, temperatures and one atmosphere total pressure, Am. J. Sci., 238, 780-799, doi:10.2475/ajs.283.7.780, 1983.

Murata, A. and Saito, S.: Decadal changes in the $\mathrm{CaCO}_{3}$ saturation state along $179^{\circ} \mathrm{E}$ in the Pacific Ocean, Geophys. Res. Lett., 39, L12604, doi:10.1029/2012GL052297, 2012.

Ono, T., Midorikawa, T., Watanabe, Y. W., Tadokoro, K., and Saino, T.: Temporal increases of phosphate and apparent oxygen utilization in the subsurface waters of western subarctic Pacific from 1968 to 1998, Geophys. Res. Lett., 28, 3285-3288, doi:10.1029/2001GL012948, 2001.

Ono, T., Tadokoro, K., Midorikawa, T., Nishioka, J., and Saino, T.: Multi-decadal decreases of net community production in the western subarctic North Pacific, Geophys. Res. Lett., 29, 1186, 4 pp., doi:10.1029/2001GL014332, 2002.

Orr, J. C., Fabry, V. J., Aumont, O., Bopp, L., Doney, S. C., Feely, R. A., Gnanadesikan, A., Gruber, N., Ishida, A., Joos, F., Key, R. M., Lindsay, K., Maier-Reimer, E., Matear, R., Monfray, P., Mouchet, A., Najjar, R. G., Plattner, G.-K., Rodgers, K. B., Sabine, C. L., Sarmiento, J. L., Schlitzer, R., Slater, R. D., Totterdell, I. J., Weirig, M.-F., Yamanaka, Y., and Yool, A.: Anthropogenic ocean acidification over the twenty-first century and its impact on calcifying organisms, Nature, 437, 681-686, doi:10.1038/nature04095, 2005.

Osafune, S., and Yasuda, I.: Bidecadal variability in the intermediate waters of the northwestern subarctic Pacific and the Okhotsk Sea in relation to 18.6-year period nodal tidal cycle, J. Geophys. Res., 111, C05007, doi:10.1029/2005JC003277, 2006.

Pierrot, D. E. L. and Wallace, D. W. R.: MS Excel program developed for $\mathrm{CO}_{2}$ System Calculations, ORNL/CDIAC-105, Oak Ridge, Tennessee, Carbon Dioxide Information Analysis Center, Oak Ridge National Laboratory, US Department of Energy, 2006.

Sabine, C. L., Feely, R. A., Key, R. M., Bullister, J. L., Millero, F. J., Lee, K., Peng, T.-H., Tilbrook, B., Ono, T., and Wong, C. S.: Distribution of anthropogenic $\mathrm{CO}_{2}$ in the Pacific Ocean, Global Biogeochem. Cycles, 16, 1083, doi:10.1029/2001GB001639, 2002.

Sagawa, T., Kuroyanagi, A., Irino, T., Kuwae, M. and Hodakaa, $\mathrm{K}$. .: Seasonal variations in planktonic foraminiferal flux and oxygen isotopic composition in the western North Pacific: Implications for paleoceanographic reconstruction, Mar. Micropaleontol., 100, 11-20, doi:10.1016/j.marmicro.2013.03.013, 2012.

Sarma, V. V. S. S., Ono, T., and Saino T.: Increase of total alkalinity due to shoaling of aragonite saturation horizon in the Pacific and Indian Oceans: Influence of anthropogenic carbon inputs, Geophys. Res. Lett., 29, doi:10.1029/2002GL015135, 2002.
Takahashi, T., Sutherland, S. C., Feely, R. A. and Wanninkhof R.: Decadal change of the surface water $\mathrm{pCO}_{2}$ in the North Pacific: A synthesis of 35 years of observations, J. Geophys. Res., 111, C07S05, doi:10.1029/2005JC003074, 2006.

Steinberg, D. K., Cope, J. S., Wilson, S. E., and Kobari, T.: A comparison of mesopelagic mesozooplankton community structure in the subtropical and subarctic North Pacific Ocean, DeepSea Res. Pt. II, 55, 1615-1635, doi:10.1016/j.dsr2.2008.04.025, 2008.

Takatani, Y., Sasano, 1 D., Nakano, T., Midorikawa, T., and Ishii, M.: Decrease of dissolved oxygen after the mid-1980s in the western North Pacific subtropical gyre along the $137^{\circ} \mathrm{E}$ repeat section, Global Biogeochem. Cycles, 26, GB2013, doi:10.1029/2011GB004227, 2012.

Tsurushima, N., Nojiri, Y., Imai, K. and Watanabe S.: Seasonal variations of carbon dioxide system and nutrients in the surface mixed layer at Station KNOT $\left(44^{\circ} \mathrm{N}, 155^{\circ} \mathrm{E}\right)$ in the subarctic North Pacific, Deep Sea Res. Pt II, 49, 5377-5394, doi:10.1016/S0967-0645(02)00197-2, 2002.

Ueno, H., and I. Yasuda.: Distribution and formation of the mesothermal structure (temperature inversions) in the North $\mathrm{Pa}$ cific subarctic region, J. Geophys. Res., 105, 16885-16897, doi:10.1029/2000JC900020, 2000.

Wakita, M., Watanabe, S., Murata, A., Tsurushima, N., and Honda, M.: Decadal change of dissolved inorganic carbon in the subarctic western North Pacific Ocean, Tellus B, 62, 608-620, doi:10.1111/j.1600-0889.2010.00476.x, 2010a.

Wakita, M., Watanabe, S., Murata, A., Honda, M., and Tsurushima, N.: Hydrographic Data Report at Station KNOT during the 1992-2008 cruises, available at: http://cdiac.ornl.gov/ftp/oceans/Moorings/KNOT/, Carbon Dioxide Information Analysis Center, Oak Ridge National Laboratory, US Department of Energy, Oak Ridge, Tennessee, doi:10.3334/CDIAC/otg.TSM_KNOT_1992-2008, 2010b.

Wakita, M., Watanabe, S., Murata, A., and Honda. M.: Hydrographic and $\mathrm{CO}_{2}$ Data Report at Station K2 during the 1999-2008 cruises, available at: http://cdiac.ornl. gov/ftp/oceans/Moorings/TS_K2/, Carbon Dioxide Information Analysis Center, Oak Ridge National Laboratory, US Department of Energy, Oak Ridge, Tennessee, doi:10.3334/CDIAC/otg.TSM_K2_1999-2008, 2010c.

Watanabe, Y. W., Shigemitsu, M., and Tadokoro T.: Evidence of a change in oceanic fixed nitrogen with decadal climate change in the North Pacific subpolar region. Geophys. Res. Lett., 35, L01602, doi:10.1029/2007GL032188, 2008.

Weiss, R.: Solubility of Nitrogen, Oxygen and Argon in water and seawater, Deep-Sea Res., 17, 721-735, doi:10.1016/00117471(70)90037-9, 1970. 